\title{
Pleomorphic adenoma of the hard palate
}

\author{
Manish Gupta, ${ }^{1}$ Monica Gupta ${ }^{2}$
}

1 Department of ENT, Gian Sagar Medical College, Chandigarh, India

${ }^{2}$ Department of Medicine, Government Medical College and Hospital, Chandigarh, India

\section{Correspondence to}

Dr Monica Gupta;

monicamanish2001@gmail.com
To cite: Gupta $\mathrm{M}_{\text {, }}$ Gupta M. BMJ Case Rep Published online: [please include Day Month Year] doi:10.1136/bcr-2013008969

\section{DESCRIPTION}

A 43-year-old woman reported to the outpatient department with complaint of painless swelling in palatal region since 9 months. On examination there was $3 \mathrm{~cm} \times 2.5 \mathrm{~cm}$ well demarcated swelling over hard palate in midline (figure 1). The overlying mucosa was intact but bulging at places. On palpation the swelling was non-tender, firm and fixed to underlying bone. There was no cervical lymphadenopathy. Fine needle aspiration cytology suggested benign tumour with features characteristic of pleomorphic adenoma. CT showed $3 \times 2.4 \times 2.3 \mathrm{~cm}$ swelling on midline hard palate with underlying bone resorption (figure 2). The patient was operated upon, under general anaesthesia. Wide excision of tumour with safe margin and drilling of under surface bone was done to avoid recurrence. There was no complication postoperatively and the raw area healed well within 1 month. There has been no recurrence in 1 year follow-up.

Salivary gland tumours account for less than 3\% of the head and neck tumours. ${ }^{1}$ Among all salivary gland tumours, pleomorphic adenoma is the most frequently encountered lesion, accounting for approximately $60 \%$ of all salivary gland neoplasms. ${ }^{2}$ Pleomorphic adenoma is also the most common benign tumour of minor salivary glands and the palate is the most common site. The second most common site is the upper lip followed by buccal mucosa. ${ }^{3}$ It is also called mixed tumour because it has both epithelial and connective tissue elements.

Intraoral pleomorphic adenoma appears as slowly growing painless mass usually in the fourth or fifth decade of life. Patients typically present with a smooth painless enlarging mass. Although it is a benign tumour, it lacks fibrous capsule, thus has a tendency to be locally aggressive. In a small number of cases, a benign pleomorphic adenoma may degenerate into a malignant tumour. Simple enucleation of this tumour has a high local recurrence rate and thus treatment is wide local excision with the removal of periosteum or bone if they are involved. Rupture of the capsule or tumour spillage is also believed to increase the risk of recurrence, so meticulous dissection is important. The differential diagnosis includes palatal abscess, odontogenic and non-odontogenic cysts, fibroma, lipoma, neurofibroma, neurilemmoma and common intraoral diseases like condyloma acuminata, oral papilloma and squamous cell carcinoma. The palatal abscess or cyst will have fluctuation on palpation, the malignancy of minor salivary gland or of epithelium will often present with erosion of overlying mucosa and bleeding or pain, the benign growth-like torus palatinus will be bony hard on palpation and has irregular appearance, the tumour extension from nasal cavity or maxillary sinus may be ruled out on radiological investigation like $\mathrm{x}$-ray paranasal sinus Water's view

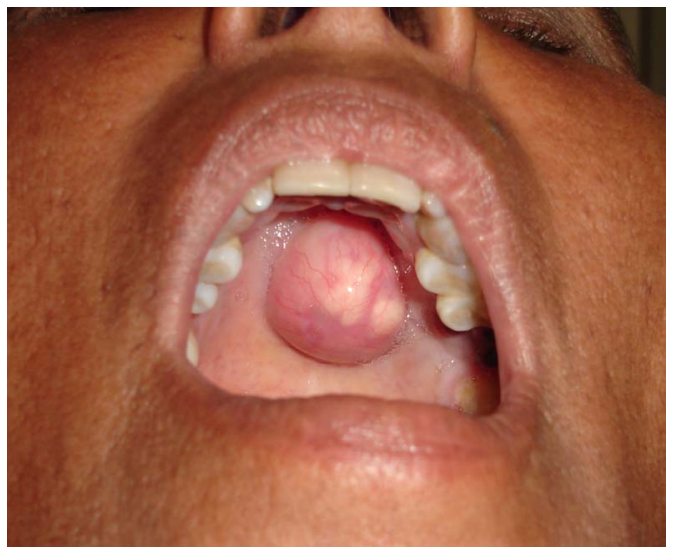

Figure 1 Clinical photograph showing $3 \times 2.5 \mathrm{~cm}$ intraoral midline palatal mass.

or CT. The soft tissue benign tumour can only be differentiated by the histopathological investigation like FNAC or incisional biopsy.

\section{Learning points}

- Intraoral pleomorphic adenoma appears as slowly growing painless mass, thus patients often seek medical attention late.

- Since the majority of minor salivary gland neoplasms arising in the palate are malignant, careful patient evaluation and a preoperative diagnosis of pleomorphic adenoma by cytopathology and radioimaging is advised.

- Complete surgical excision with a wide margin provides definitive diagnosis and treatment for this rare tumour.

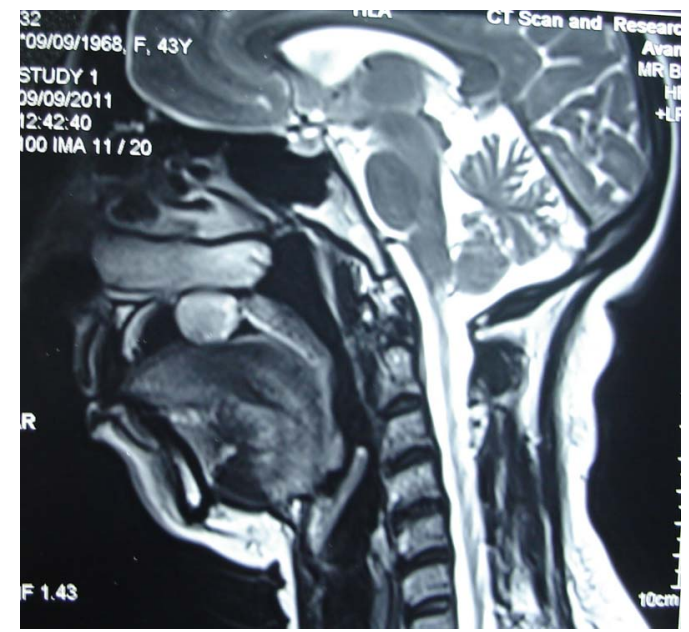

Figure 2 Sagittal reconstructed CT image showing hard palate mass with underlying bone erosion. 
Competing interests None.

Patient consent Obtained.

Provenance and peer review Not commissioned; externally peer reviewed.

\section{REFERENCES}

1 Luna MA, Batsakis JG, El-Naggar AK. Salivary gland tumors in children. Ann Otol Rhinol Laryngol 1991;100:869-71.
2 Pinkston JA, Cole P. Incidence rates of salivary gland tumors: results from a population based study. Otolaryngol Head Neck Surg 1999;120:834-40.

3 Jansisyanont $\mathrm{P}$, Blanchaert RH Jr, Ord RA. Intraoral minor salivary gland neoplasm: a single institution experience of 80 cases. Int J Oral Maxillofac Surg 2002:31:257-61.

Copyright 2013 BMJ Publishing Group. All rights reserved. For permission to reuse any of this content visit http://group.bmj.com/group/rights-licensing/permissions.

BMJ Case Report Fellows may re-use this article for personal use and teaching without any further permission.

Become a Fellow of BMJ Case Reports today and you can:

- Submit as many cases as you like

Enjoy fast sympathetic peer review and rapid publication of accepted articles

- Access all the published articles

- Re-use any of the published material for personal use and teaching without further permission

For information on Institutional Fellowships contact consortiasales@bmjgroup.com

Visit casereports.bmj.com for more articles like this and to become a Fellow 